\title{
Estimation of Serum Liver Enzymes Activities in Awassi Sheep
}

\author{
H.A.H. Al-Hadithy ${ }^{\circledR 1}$; N.M. Badawi ${ }^{1}$ and M.M. Mahmood ${ }^{2}$ \\ ${ }^{1}$ Department of Internal and Preventive Medicine, ${ }^{2}$ Unit of Zoonotic Diseases, College of \\ Veterinary Medicine, Baghdad University, Iraq \\ harithal.hadithy@gmail.com
}

Accepted on 26/2/2013

Summary

The current study was conducted on 152 clinically normal Awassi sheep to evaluate serum activities of alanine aminotranferase (ALT), aspartate amino-transferase (AST), alkaline phosphatase (ALP) and gamma glutamyltransferase (GGT) in Baghdad governorate / Iraq. Sheep were divided into males; 62 ram lambs and rams, 90 females; ewe lambs, pregnant and lactating ewes both aged 7 to 48 months. The samples were collected from October 2011 until March 2012, and the sera were used for measurement of serum liver enzymes. The results revealed that the range and mean \pm SEM of these enzymes were as follows : serum ALT $3.5-24 \mathrm{U} / \mathrm{L}$ and $9.66 \pm 0.31 \mathrm{U} / \mathrm{L}$, serum AST $25-220 \mathrm{U} / \mathrm{L}$ and $71.83 \pm 3.09 \mathrm{U} / \mathrm{L}$, serum ALP $59-300 \mathrm{U} / \mathrm{L}$ and $139.86 \pm 3.56 \mathrm{U} / \mathrm{L}$ and serum GGT $2.3-38.2 \mathrm{U} / \mathrm{L}$ and $15.9 \pm 0.78 \mathrm{U} / \mathrm{L}$ respectively. There were significant differences $(\mathrm{P}<0.05)$ between males and females in serum ALT and GGT activities. The effect of age on serum liver enzymes was studied in males. However, according to physiologic status a significant difference $(\mathrm{P}<0.05)$ noticed in serum enzymes values of all groups. In conclusion, present data recorded range references and mean \pm SE for serum liver enzymes in normal Iraqi Awassi sheep with significant differences in activities of these enzymes between males and females a well as between subgroups in both sexes.

\section{Keywords: Serum, liver enzymes, Iraqi Awassi sheep.}

\section{Introduction}

Awassi sheep are considered the most numerous and indigenous breed in Iraq. They are multipurpose breed, used for meat, milk and wool production with high adaptability to cruel environment and poor nutrition (1 and 2). There are many studies about the blood constituents of Awassi sheep including minerals and some electrolytes (3, 4, 5, 6 and 7) in different age groups and for both sex, while few researches were done to estimate liver enzymes. Alanine transaminase (ALT) is an enzyme normally found in hepatocytes only, Aspartate transaminase (AST) present in hepatocytes, red blood cells, and in cardiac and skeletal muscles. Alkaline phosphatase (ALP) is an intrahepatic enzyme found in lining cells of the biliary ducts, bone and placenta, while Gamma glutamyl transferase (GGT) is restricted to hepatocytes (8 and 9). Those enzymes are considered as biomarkers of hepatic affections (9).

Certain changes in values of some liver function enzymes occur during pregnancy.
Routine liver enzymes frequently include total and conjugated bilirubin, aminotransferases, and ALP. The effects of physiologic status on the serum enzymes in adult Awassi ewes cannot be described adequately (10). Although some countries were developed their researches in the field of enzymology related to sheep, in Iraq, little information was noted about liver enzymes in grazing and inbreed Awassi sheep. Therefore, this study was conducted to estimate the normal levels of four liver enzymes concentrations at different ages in clinically healthy Iraqi Awassi sheep.

\section{Materials and Methods}

Blood samples were collected into plain tubes from jugular vein puncture of 152 clinically normal Awassi sheep (62 males which subdivided into 24 ram lambs aged 7-9 months and 38 rams; 21 rams aged $1.5-2$ years, and 17 rams aged $>2$ to 4 years, and 90 females which subdivided into 30 ewe lambs aged $7-12$ months, 30 pregnant ewes aged $1-$ 4 years and 30 lactating ewes aged $1.5-4$ 
years) in Baghdad governorate from October 2011 until March 2012. Eighty seven out of 152 sheep were investigated for GGT (29 males; 10 ram-lambs aged 7-9 months , 11 rams aged 1.5-2 years and 8 rams aged $>2-4$ years and 58 females; 19 ewe lambs aged 7-12 months , 20 pregnant ewes aged $1-4$ years and 19 lactating ewes aged 1.5-4 years). Sera were separated after centrifugation for 5 minutes at $3000 \mathrm{rpm}$ (11), then used directly for measurements of serum ALT, AST, ALP, and GGT enzymes. ALT, AST, ALP and GGT were determined according to the colorimetric methods of $(12,13,14$ and 15).

Statistical analysis was performed using SAS program. Data were subjected to analysis of variance (ANOVA) and significant means were compared by $\mathrm{T}$-test at a level $(\mathrm{P}<0.05)$.

\section{Results and Discussion}

The serum values of the measured liver enzymes ALT, AST, ALP, and GGT in clinically healthy Awassi sheep independent of any subdivision were as follows: $9.66 \pm 0.31$ $\mathrm{U} / \mathrm{L}$ ranged $3.5-24 \mathrm{U} / \mathrm{L}, 71.83 \pm 3.09 \mathrm{U} / \mathrm{L}$ ranged $25-220 \mathrm{U} / \mathrm{L}, 139.86 \pm 3.56 \mathrm{U} / \mathrm{L}$ ranged $59-300 \mathrm{U} / \mathrm{L}$ and $15.9 \pm 0.78 \mathrm{U} / \mathrm{L}$ ranged $2.3-38.2 \mathrm{U} / \mathrm{L}$ respectively (table, 1 ).

The results obtained in the current study was lower than those recorded by international studies (16 and 17), whereas (18) recorded serum ALT and GGT higher than our range, while serum ALP was lower. This may be attributed to the fact that the grazing and indigenous sheep fed multiple types of poor quality grass with little amounts of concentrated ration (grains), the feeding system have not managed correctly, and variation in the environment. For this reason, our findings was slightly lower than those gained by (19) who emphasis the effect of nutritional treatments and heat stress on Awassi sheep during spring and summer, and they found that the type of food alter the levels of liver enzymes toward decrement about $16 \%$ in summer.

The enzymes values were presented according to sex in table,2. The serum ALT activity was $11.04 \pm 0.51 \mathrm{U} / \mathrm{L}$ in males and $8.71 \pm 0.36 \mathrm{U} / \mathrm{L}$ in females with a significant difference between them $(\mathrm{P}<0.05)$. Serum AST values were found to be $74.52 \pm 4.48 \mathrm{U} / \mathrm{L}$ in males, while in females was $69.98 \pm 4.23$ U/L. Serum ALP activities was $147.80 \pm 4.65$ $\mathrm{U} / \mathrm{L}$ in males and $134.38 \pm 5.03 \mathrm{U} / \mathrm{L}$ in females. There was no significant difference between males and females in serum AST and ALP activities. On the other hand, the GGT activity was found to be $18.60 \pm 1.52 \mathrm{U} / \mathrm{L}$ in males and $14.59 \pm 0.85 \mathrm{U} / \mathrm{L}$ in females. The serum GGT activity was significantly higher in males compared to females. This may be due to hormonal effect. However, our findings disagree with (20), despite the fact that the number of sheep surveyed was low, may be explain the negative differences according to sex. Also, the current results disagree with (21) who found significant differences in AST and ALP activities in relation to sex in their study conducted on 377 apparently healthy sheep.

The effect of age on serum ALT, AST, ALP, and GGT activities in males are presented in table 3. The serum ALT activity in the three age groups were as follows: 11.11 $\pm 0.72 \mathrm{U} / \mathrm{L}, 9.99 \pm 0.84 \mathrm{U} / \mathrm{L}$ and $12.25 \pm 1.13$ $\mathrm{U} / \mathrm{L}$ respectively with no significant differences between them, while serum AST activities were $61.93 \pm 4.11 \mathrm{U} / \mathrm{L}, 83.76 \pm 5.65$ $\mathrm{U} / \mathrm{L}$ and $80.88 \pm 13.15 \mathrm{U} / \mathrm{L}$ with significant differences between 7-9 months and 1.5-2 years age group. Serum ALP activities were as follows $142.83 \pm 8.31 \mathrm{U} / \mathrm{L}, 160.76 \pm 8.23 \mathrm{U} / \mathrm{L}$ and $138.82 \pm 5.95 \mathrm{U} / \mathrm{L}$ with no significant difference between them. On the other hand, serum GGT activities were significantly higher in 7-9 months and 1.5-2 years groups in comparison with those $>2-4$ years age groups. The values were $22.87 \pm 2.0 \mathrm{U} / \mathrm{L}, 20.95 \pm 2.34$ $\mathrm{U} / \mathrm{L}$ and $9.69 \pm 0.90 \mathrm{U} / \mathrm{L}$ respectively. There was correlation between serum ALT and AST activities in male age groups $(\mathrm{r}=0.30, \mathrm{P}=$ $0.01)$.

The findings of the current study were partially in consent with a study of (22) that studied 98 goat and 22 sheep and compared the ALT and AST enzymes levels according to their gender and age, and they found no significant differences according to their age and sex. However, our findings disagree with 
(21) who found significant differences only in ALP levels according to age.

On the other hands, recent studies in Iraq were done by (23) to estimate the relationship between some liver enzymes like AST and ALT periodically with the breed of sheep, and growth of wool, they found significant increase of AST and ALT enzymes in some breeds. Moreover, they found no effect of age and physiologic status on these enzymes as we mentioned in our results.

Serum liver enzymes' activities according to physiologic status are presented in table 4 . Serum ALT activities in ram lambs, rams, ewe lambs, pregnant and lactating ewes were as follows : $11.11 \pm 0.72 \mathrm{U} / \mathrm{L}, 11.00 \pm 0.70 \mathrm{U} / \mathrm{L}$, $8.77 \pm 0.48 \mathrm{U} / \mathrm{L}, 9.66 \pm 0.81 \mathrm{U} / \mathrm{L}$ and $7.69 \pm$ $0.48 \mathrm{U} / \mathrm{L}$ respectively. There was highly significantly difference between serum ALT in ram lambs and rams compared to that of ewe lambs and lactating ewes. The serum AST activities in ram lambs, rams, ewe lambs, pregnant and lactating ewes were as follows : $61.93 \pm 4.11 \mathrm{U} / \mathrm{L}, 82.47 \pm 6.56 \mathrm{U} / \mathrm{L}, 53.28 \pm$ $4.45 \mathrm{U} / \mathrm{L}, 72.16 \pm 8.76 \mathrm{U} / \mathrm{L}$ and $84.50 \pm 7.14$ $\mathrm{U} / \mathrm{L}$ respectively.

The serum values of AST enzyme were significantly higher in rams and lactating ewes compared to ram lambs and ewe lambs. The serum ALP activities in ram lambs, rams, ewelambs, pregnant and lactating ewes were
$142.83 \pm 8.31 \mathrm{U} / \mathrm{L}, 150.94 \pm 5.50 \mathrm{U} / \mathrm{L}$, $157.60 \pm 6.67 \mathrm{U} / \mathrm{L}, 136.03 \pm 10.76 \mathrm{U} / \mathrm{L}$ and $109.53 \pm 5.71 \mathrm{U} / \mathrm{L}$ respectively. In fact, the activity of serum ALP was significantly lower in lactating ewes in comparison with other groups. Finally, serum GGT values were significantly lower in pregnant ewes compared to ram lambs, rams, and lactating ewes groups.

In above drop information, the differences between values of our observations and other studies on sheep, it could be assumed to the individual variation or genetic factors. These results are consistent with (24) who explained that activity of ALT, AST and GGT enzymes could be recommended as a reliable liver status criterion in sheep. Also, our study is in line with (25) who attributed elevated liver enzymes to higher activity of Awassi rams in breeding season, they found that rams treated with Gonadotropin Releasing Hormone $(\mathrm{GnRH})$ revealed more elevated values of ALT, AST, and ALP in comparison with control groups inside and outside breeding seasons.

In conclusion, this study recorded reference range and mean \pm SEM of serum liver enzymes activities in clinically healthy Iraqi Awassi sheep with significant differences between males and females a well as between subgroups in both sexes.

\section{Table, 1: Serum values of ALT, AST, ALP and GGT activities in Awassi sheep $(\mathrm{M} \pm \mathrm{SE})$}

\begin{tabular}{|cccc|}
\hline Liver enzymes & No. of sheep & Range & Mean \pm SEM \\
\hline Serum ALT (U/L) & 152 & $\mathbf{3 . 5}-\mathbf{2 4}$ & $\mathbf{9 . 6 6} \pm \mathbf{0 . 3 1}$ \\
\hline Serum AST $(\mathbf{U} / \mathbf{L})$ & $\mathbf{1 5 2}$ & $\mathbf{2 5}-\mathbf{2 2 0}$ & $\mathbf{7 1 . 8 3} \pm \mathbf{3 . 0 9}$ \\
\hline Serum ALP $(\mathbf{U} / \mathbf{L})$ & $\mathbf{1 5 2}$ & $\mathbf{5 9}-\mathbf{3 0 0}$ & $\mathbf{1 3 9 . 8 6} \pm \mathbf{3 . 5 6}$ \\
\hline Serum GGT $(\mathbf{U} / \mathrm{L})$ & $\mathbf{8 7}$ & $\mathbf{2 . 3 - 3 8 . 2}$ & $\mathbf{1 5 . 9} \pm \mathbf{0 . 7 8}$ \\
\hline
\end{tabular}

Table, 2: Serum values of ALT, AST, ALP and GGT activities according to sex in Awassi sheep (M \pm SE)

\begin{tabular}{|c|c|c|c|c|}
\hline \multirow[t]{2}{*}{ Gender } & \multicolumn{4}{|l|}{ Liver Enzymes } \\
\hline & $\begin{array}{l}\mathbf{A L T} \\
(\mathbf{U} / \mathbf{L})\end{array}$ & $\begin{array}{l}\text { AST } \\
\text { (U/L) }\end{array}$ & $\begin{array}{l}\text { ALP } \\
\text { (U/L) }\end{array}$ & $\begin{array}{l}\text { GGT } \\
(\mathbf{U} / \mathbf{L})\end{array}$ \\
\hline Males & $\begin{array}{l}4-24 \\
11.04 \pm 0.51 \\
(n=62)\end{array}$ & $\begin{array}{l}36-220 \\
74.52 \pm 4.48 \quad a \\
(n=62)\end{array}$ & $\begin{array}{l}73-229 \\
147.8 \pm 4.65 \quad a \\
(n=62)\end{array}$ & $\begin{array}{l}6-33.58 \\
18.6 \pm 1.52 \text { a } \\
(n=29)\end{array}$ \\
\hline Females & $\begin{array}{l}3.5-17 \\
8.71 \pm 0.36 \\
(n=90)\end{array}$ & $\begin{array}{l}25-210 \\
69.98 \pm 4.23 \text { a } \\
(n=90)\end{array}$ & $\begin{array}{l}59-300 \\
134.38 \pm 5.03 \text { a } \\
(n=90)\end{array}$ & $\begin{array}{l}2.3-38.2 \\
14.59 \pm 0.85 b \\
(n=58)\end{array}$ \\
\hline
\end{tabular}

Different letters vertically refers to presence of significant differences at $(\mathbf{P}<\mathbf{0 . 0 5})$. 
Table 3: The effect of age on serum liver enzymes activities in male Awassi sheep $(\mathrm{M} \pm \mathrm{SE})$

\begin{tabular}{|c|c|c|c|c|}
\hline \multirow[b]{2}{*}{ Age } & \multicolumn{4}{|l|}{ Liver Enzymes } \\
\hline & $\begin{array}{l}\mathbf{A L T} \\
\text { (U/L) }\end{array}$ & $\begin{array}{l}\mathbf{A S T} \\
\text { (U/L) }\end{array}$ & $\begin{array}{l}\mathbf{A L P} \\
\text { (U/L) }\end{array}$ & $\begin{array}{l}\text { GGT } \\
\text { (U/L) }\end{array}$ \\
\hline $7-9$ months & $\begin{array}{l}5-21.6 \\
11.11 \pm 0.72 \quad a \\
(n=24)\end{array}$ & $\begin{array}{l}36-115 \\
61.93 \pm 4.11 \quad b \\
(n=24)\end{array}$ & $\begin{array}{l}73-217 \\
142.83 \pm 8.31 a \\
(n=24)\end{array}$ & $\begin{array}{l}16.2-33.58 \\
22.87 \pm 2.00 \text { a } \\
(n=10)\end{array}$ \\
\hline $1.5-2$ years & $\begin{array}{l}4-19.5 \\
9.99 \pm 0.84 \quad a \\
(n=21)\end{array}$ & $\begin{array}{l}41-146 \\
83.76 \pm 5.65 a \\
(n=21)\end{array}$ & $\begin{array}{l}95-229 \\
160.76 \pm 8.23 a \\
(n=21)\end{array}$ & $\begin{array}{l}11.58-31.7 \\
20.95 \pm 2.34 \text { a } \\
(n=11)\end{array}$ \\
\hline$>2-4$ years & $\begin{array}{l}4-24 \\
12.25 \pm 1.13 a \\
(n=17)\end{array}$ & $\begin{array}{l}38-220 \\
80.88 \pm 13.15 a b \\
(n=17)\end{array}$ & $\begin{array}{l}82-187 \\
138.82 \pm 5.95 a \\
(n=17)\end{array}$ & $\begin{array}{l}6-12.74 \\
9.69 \pm 0.90 \quad b \\
(n=8)\end{array}$ \\
\hline
\end{tabular}

Different letters vertically refers to presence of significant differences at $(P<0.05)$.

Table, 4: Serum liver enzymes activities according to physiologic status in Awassi sheep $(\mathrm{M} \pm \mathrm{SE})$

\begin{tabular}{|c|c|c|c|c|}
\hline \multirow[b]{2}{*}{ Groups } & \multicolumn{4}{|l|}{ Liver Enzymes } \\
\hline & $\begin{array}{l}\text { ALT } \\
\text { (U/L) }\end{array}$ & $\begin{array}{l}\text { AST } \\
\text { (U/L) }\end{array}$ & $\begin{array}{l}\text { ALP } \\
\text { (U/L) }\end{array}$ & $\begin{array}{l}\text { GGT } \\
\text { (U/L) }\end{array}$ \\
\hline Ram lambs & $\begin{array}{l}5-21.6 \\
11.11 \pm 0.72 \text { a } \\
(n=24)\end{array}$ & $\begin{array}{l}36-115 \\
61.93 \pm 4.11 b \\
(n=24)\end{array}$ & $\begin{array}{l}73-217 \\
142.83 \pm 8.31 \text { a } \\
(n=24)\end{array}$ & $\begin{array}{l}16.2-33.58 \\
22.87 \pm 2.00 \text { a } \\
(n=10)\end{array}$ \\
\hline Rams & $\begin{array}{l}4-24 \\
11.00 \pm 0.70 a \\
(n=38)\end{array}$ & $\begin{array}{l}38-220 \\
82.47 \pm 6.56 a \\
(n=38)\end{array}$ & $\begin{array}{l}82-229 \\
150.94 \pm 5.50 a \\
(n=38)\end{array}$ & $\begin{array}{l}6-31.7 \\
16.21 \pm 1.90 a \\
(n=19)\end{array}$ \\
\hline Ewe lambs & $\begin{array}{l}4.8-17 \\
8.77 \pm 0.48 \text { b } \\
(n=30)\end{array}$ & $\begin{array}{l}29-150 \\
53.28 \pm 4.45 b \\
(n=30)\end{array}$ & $\begin{array}{l}97-230 \\
157.60 \pm 6.67 a \\
(n=30)\end{array}$ & $\begin{array}{l}4-31.3 \\
15.39 \pm 1.61 a b \\
(n=19)\end{array}$ \\
\hline Pregnant ewes & $\begin{array}{l}4-13.8 \\
9.66 \pm 0.81 \text { ab } \\
(n=30)\end{array}$ & $\begin{array}{l}25-210 \\
72.16 \pm 8.76 \text { ab } \\
(n=30)\end{array}$ & $\begin{array}{l}82-300 \\
136.03 \pm 10.76 a \\
(n=30)\end{array}$ & $\begin{array}{l}2.3-23 \\
11.70 \pm 1.08 \quad b \\
(n=20)\end{array}$ \\
\hline Lactating ewes & $\begin{array}{l}3.5-12.8 \\
7.69 \pm 0.48 \quad b \\
(n=30)\end{array}$ & $\begin{array}{l}36-178 \\
84.50 \pm 7.14 a \\
(n=30)\end{array}$ & $\begin{array}{l}59-186 \\
109.53 \pm 5.71 \text { b } \\
(n=30)\end{array}$ & $\begin{array}{l}8.1-38.2 \\
16.83 \pm 1.54 a \\
(n=19)\end{array}$ \\
\hline
\end{tabular}

Different letters vertically refers to presence of significant differences at $(\mathbf{P}<0.05)$.

$$
\text { References }
$$

1. Talafha, A. Q. and Ababneh, M.M. (2011). Awassi sheep reproduction and milk production: review. Trop. Anim. Hlth. Prod., 43(7): 1319-26.

2. Wikipedia, (2012). Awassi sheep, Wikipedia, the free encyclopedia. P: 1-2.

3. Abdelrahman, M.M. and Hunaiti, D.A. (2008). The effect of dietary yeast and protected methionine on performance and trace minerals status of growing Awassi lambs. Livestock Sci., 115(2-3): 235-241.

4. Jawasreh, K., Awawdeh, F., Bani Ismail, Z.; Al-Rawashdeh, O. and Al-Majali, A. (2010). Normal hematology and selected serum biochemical values in different genetic lines of Awassi ewes in Jordan. Intern. J. Vet. Med.; 7(2).
5. Abdelrahman, M.M. (2012). Status of some minerals of growing Awassi lambs fed calcium salt fat and protected sulfur amino acid. J. Anim. Plant Sci., 13(1): 1698-1703.

6. AL-Hadithy, H. AH.; AL-Badawi, N.M. and Mahmood, M.M. (2012). Status of some serum electrolytes concentrations in Iraqi Awassi Sheep. Int. J. Adv. Biol. Res., 2(3): 540-544.

7. AL-Hadithy, H. and AL-Badawi, N.M. (2012). Evaluation of Specific Biochemical Values in Clinically Normal and Anemic Awassi Sheep. Int. J. Sci. Nat., 3(3): 688691.

8. Copeland, R.A. (2000). Enzymes. In: A Practical Introduction to Structure, Mechanism and Data Analysis. $2^{\text {nd }}$ Ed. A 
John Wiley and Sons, INC., Publication New York / Chichester / Weinheim / Brisbane / Singapore / Toronto.

9. Evans, G.O. (2009). Animal Clinical Chemistry: A Practical Handbook for Toxicologists and Biomedical. $2^{\text {nd }}$ Ed. Published by CRC Press, an imprint of Taylor and Francis Group. Boca Raton London New York, Chapter 2 General Enzymology, PP: 17-36.

10. Gürgöze, S.Y.; Zonturlu, A. K., Özyurtlu, N. and İçen, H. (2009). Investigation of Some Biochemical Parameters and Mineral Substance during Pregnancy and Postpartum Period in Awassi Ewes. Faculty of Veterinary Medicine, University of Kafkas. 15(6): 957-963.

11. Coles, E.H. (1986). Veterinary Clinical Pathology. $4^{\text {th }}$ Ed. Published by W.B. Saunders Company, Philadelphia, USA., London, Toronto, Mexico, Rio de Janeiro, Sydney, Tokyo, Hong Kong, PP: 114-121.

12. Bergmeyer, H.U., Scheibe, P. and Wahlefeld, A.W. (1978). Optimization of methods for aspartate aminotransferase and alanine aminotransferase. Clin. Chem., 24(1): 58-73.

13. Bowers, J.G. and McComb, R.B. (1984). A unifying reference system for clinical enzymology: aspartate aminotransferase and the International Clinical Enzyme Scale. Clin. Chem., 30(7): 1128-1136.

14. Lee, D.H.; Jacobs, D.R.; Gross, M.; Kiefe, C.I.; Roseman, J.; Lewis, C.E. and Steffes, M. (2003). Gamma-glutamyltransferase is a predictor of incident diabetes and hypertension: the Coronary Artery Risk Development in Young Adults (CARDIA) Study. Clin. Chem., 49: 1358-1366.

15. Kim, H.C.; Nam, C.M.; Jee, S.H.; Han, K.H.; Oh, D.Y. and Suh, I. (2004). Normal serum aminotransferase concentration and risk of mortality from liver disease: prospective cohort study. Br. Med. J., 328: 983-986.

16. Radostits, O. M.; Henderson, J. A.; Blood, D.C.; Arundel, J.T. and Gay, C. C. (2007). Veterinary Medicine: A Textbook of the Diseases of Cattle, Sheep, Pigs, Goats, and Horses. $11^{\text {th }}$ Ed., Bailliere, Tindall Comp. UK.
17. Kaneko, J.J. (2008). Veterinary Clinical Biochemistry of Domestic Animals. $6^{\text {th }} \mathrm{Ed}$. Elsevier Inc. PP: 882-884.

18. Aiello, S.E. (2008). The Merck Veterinary Manual. 10 ${ }^{\text {th }}$ Ed. Published by Merck and Co. Inc. Whitehouse Station N.J. USA in cooperation with Merial Limited. A Merck and Aventis Company.

19. Abdel-Samee, A.M.; Abd-Alla, O.A. and EL-Adawy, S.A. (2008). Nutritional Treatments for Alleviation of Heat Stress in Awassi Sheep Using Acacia and Olive Pulp in Subtropics. Egypt J. Comp. Pathol. Clin. Pathol., 21(1): 466- 477.

20. Porácová, J.; Fazekašová, D.; Macková, D. and Nagyova, M. (1998). The physiological values of AST and ALT in the blood serum of sheep, rabbits and horses according to sex. Chem., 52: 4-10.

21. Tibbo, M.; Woldemeskel, M.; Aragaw, K. and Rege, J.E. (2008). Serum enzyme levels and influencing factors in three indigenous Ethiopian sheep breeds. Comp. Clin. Pathol., 17(3): 149-155.

22. Kiran, S.; Bhutta, A.M.; Khan, B.A.; Durrani, S.; Ali, M.; Ali, M. and Iqba, F. (2012). Effect of age and gender on some blood biochemical parameters of apparently healthy small ruminants from Southern Punjab in Pakistan. Asian Pac. J. Trop. Biomed., 2(4): 304-306.

23. Ahmed, N. N.; Al-Dabbagh, S.F. and ALMasry, N.A. (2012). Study of Some Genetic and Non-genetic Factors Affecting Wool Growth and It's Relation with Some Blood Biochemical Components in Iraqi Sheep. Tikrit Univ. J. Agric. Sci., 1(1): in Press.

24. Antunović, Z.; Marić, I.; Zdenko S.; Mensur, V. and Josip, N. (2011). Blood metabolic profile of the dubrovnik sheep Croatian endangered breed. Maced. J. Anim. Sci., 1(1): 35-38.

25. Azawi, O.I.; Al-Khashab, A.N. and AlKadoo, N.N. (2012). Effect of Gonadotropin Releasing Hormone Treatment on Semen Characteristics and Enzymatic Activities of Awassi Rams in Breeding and Non Breeding Seasons. Iran. J. Appl. Anim. Sci., 2(1): 13-19. 


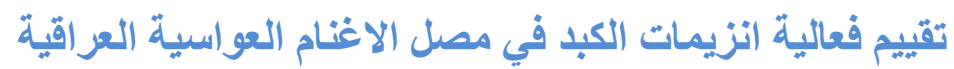

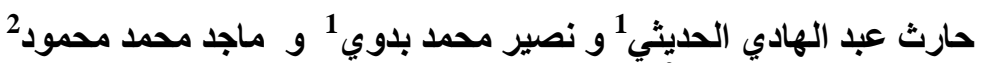

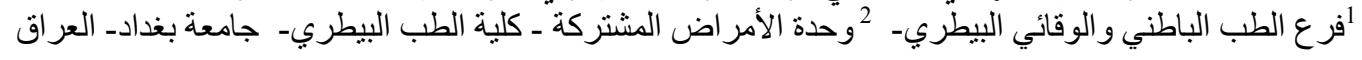

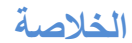

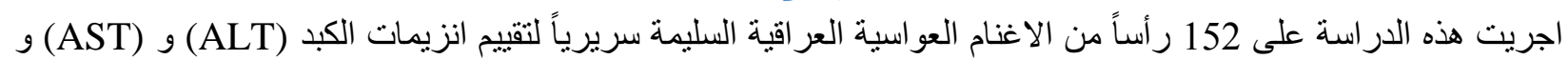

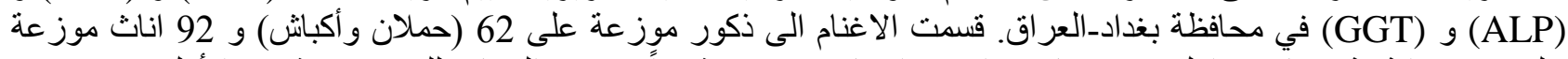

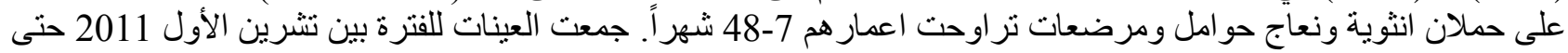

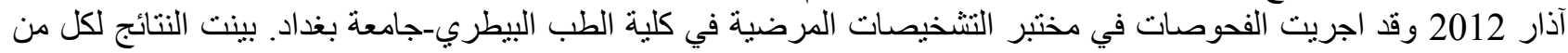

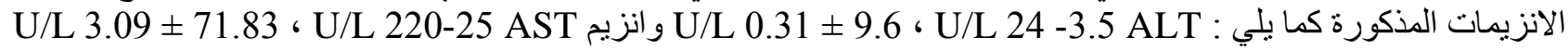

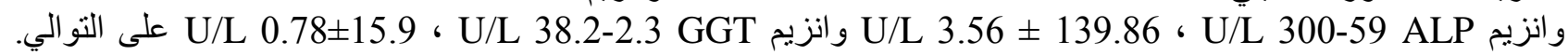

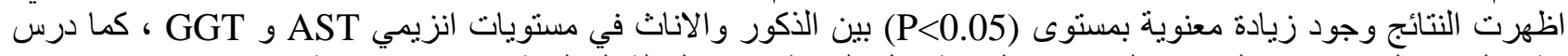

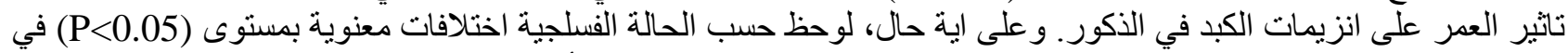

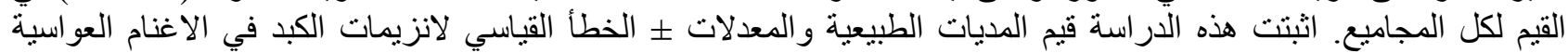

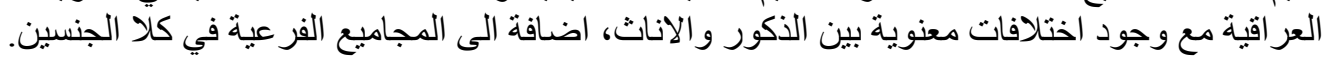

الكلمات المفتاحية : مصل , انزيمات الكبد , الاغنام العواسية العراقية. 